\title{
Narcissus, the Beam, and lung cancer
}

\author{
Gaetano Rocco, MD, FRCSEd
}

\begin{abstract}
In the management of lung cancer, the rules of engagement of stereotactic ablative radiotherapy (SABR) are not clearly defined. The potential for SABR to affect to an unprecedented level current protocols and in all disease stages emerges vehemently from the literature. However, in a time when the role of surgery is being reassessed, surgeons need to take a closer look at the evidence for the use of SABR in lung cancer patients and clearly define their indisputable role within the context of multidisciplinary teams. The myth of Narcissus exemplified in the absolute masterpiece by Caravaggio seems to represent an ideal metaphor to explain the ever-evolving interaction between surgery and SABR in lung cancer management. (J Thorac Cardiovasc Surg 2016;152:338-43)
\end{abstract}

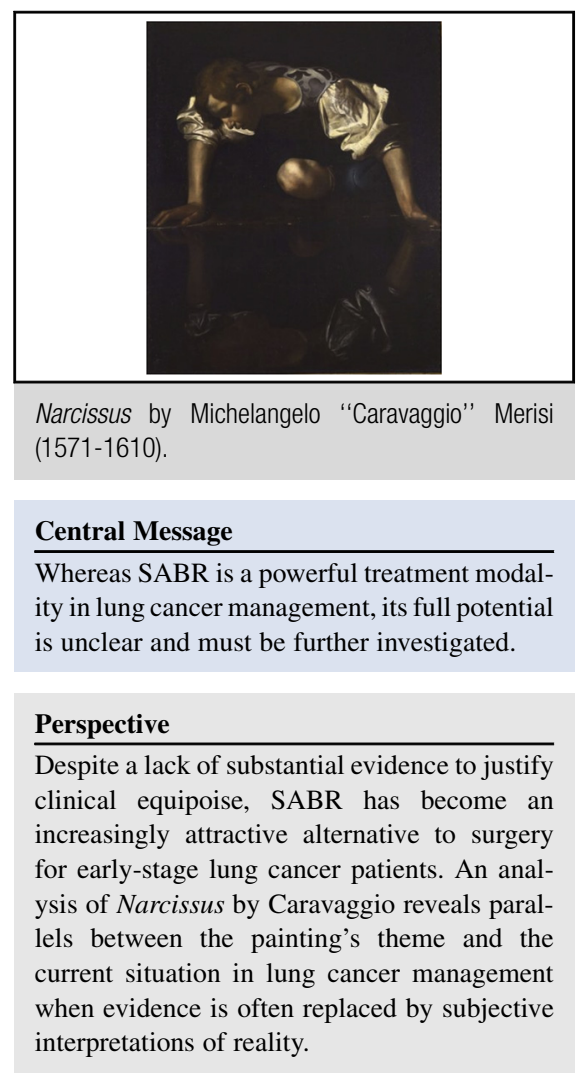

See Editorial Commentary page 344.
Among the masterpieces created by the famous Italian painter Michelangelo Merisi (1571-1610), better known as Caravaggio, one of the most renowned is Narcissus (Figure 1), which is an oil painting on canvas housed at the Palazzo Barberini, a site of the Galleria Nazionale d'Arte Antica in Rome. Caravaggio painted Narcissus between 1597 and 1599, and he drew inspiration from the myth of Narcissus from Metamorphoses, a poem by the Roman poet Ovid. Narcissus is loved by the god Apollo for his astonishing physical appearance, which in turn makes him vain and egocentric. Echo, a beautiful nymph, falls for

\footnotetext{
From the Division of Thoracic Surgery, Department of Thoracic Surgical and Medical Oncology, Istituto Nazionale Tumori, Fondazione Pascale, IRCSS, Naples, Italy. Received for publication Jan 5, 2016; revisions received March 31, 2016; accepted for publication April 24, 2016; available ahead of print May 19, 2016.

Address for reprints: Gaetano Rocco, MD, FRCSEd, Division of Thoracic Surgery, Department of Thoracic Surgical and Medical Oncology, Istituto Nazionale Tumori, Fondazione Pascale, IRCSS, Via Semmola 81, Naples, Italy (E-mail: g.rocco@ istitutotumori.na.it). $0022-5223 / \$ 36.00$

Copyright (C) 2016 by The American Association for Thoracic Surgery http://dx.doi.org/10.1016/j.jtcvs.2016.04.072
}

Narcissus but is painfully rejected by him. This leads to the goddess Nemesis becoming angry with Narcissus. Nemesis then constructs a mystification of reality to punish Narcissus for being an unreachable love. One day, the young and very attractive Narcissus sees his own reflection in a pool and falls in love with it, completely losing perception of the world around him. Stunned by the beauty of his reflection and fearful of it disappearing, Narcissus is immobilized and eventually dies of thirst and starvation.

The painting shows a young adult, who is stupefied and unaware of his surrounding environment, immersed in a penetrating and foreboding darkness (Figure 1). Caravaggio is the master of the chiaroscuro technique, which plays with the contrast of shadows and light to confer tridimensional realism to characters and situations. The same chiaroscuro dominates current lung cancer management policies, in a time when stereotactic radiotherapy is increasingly considered as a viable alternative to surgery.

Indeed, the rules of engagement for stereotactic radiotherapy have rapidly evolved over the past few years. ${ }^{1,2}$ Whether or not the chamber of resonance provided by the 


\section{Abbreviations and Acronyms}

$\mathrm{CT}=$ computed tomography

NSCLC $=$ non-small cell lung cancer

SABR $=$ stereotactic ablative radiotherapy

VATS $=$ video-assisted thoracoscopic surgery

ever-growing number of publications corresponds to hard undisputable evidence is still being debated. ${ }^{3}$ The story of stereotactic ablative radiotherapy (SABR) and early-stage lung cancer parallels the legend of Narcissus, as immortalized in Caravaggio's masterpiece. This amazing painting is about misguided self-perception, darkness and light, chiaroscuro, and the realism that is brought to life divinely with each individual paintbrush stroke.

\section{NARCISSUS}

It is obvious that Narcissus was a Surgeon. Surgery was traditionally considered the "gold standard" in management protocols for early-stage disease despite some evidence to the contrary. ${ }^{1,2}$ Over time, unchallenged surgeons become egocentric and they look with disdain at alternative therapeutic options. Surgery became an even more attractive option when the principles of minimal invasiveness started to become applied widely to reduce surgical mortality and morbidity. ${ }^{3}$ Skeptics have questioned the true oncologic value of video-assisted thoracoscopic surgery (VATS), specifically with regard to incomplete mediastinal lymphadenectomies. ${ }^{4}$ Because of this hubris, Narcissus rarely attended multidisciplinary team meetings and, when he actually attended, he always believed that he was wasting time. ${ }^{5}$

\section{ECHO}

Echo was a patient who was diagnosed recently with a disease that required-according to Narcissus-surgical intervention. To avoid a large painful incision, she wanted to opt for minimally invasive surgery. ${ }^{6}$ More specifically, Echo wanted a keyhole operation, which she anticipated would cure the disease and allow for a quick return to her normal life with the other Nymphs. ${ }^{7}$ However, after reviewing her computed tomography (CT) scan, Narcissus believed that she may require a more invasive procedure; the possibility of experiencing post-thoracotomy pain terrified her. Determined to find an alternative to surgery, Echo researched and came across SABR (ie, the Beam), which is painless and leaves no scars. ${ }^{8}$

\section{THE GODDESS NEMESIS}

Nemesis was the goddess of fortune and retribution. The story of Echo destined to suffer perennial pain drew Nemesis' attention and attracted her sense of justice. The retribution was SABR. With SABR at her disposal, Nemesis felt omnipotent and believed that she had a very attractive treatment option for

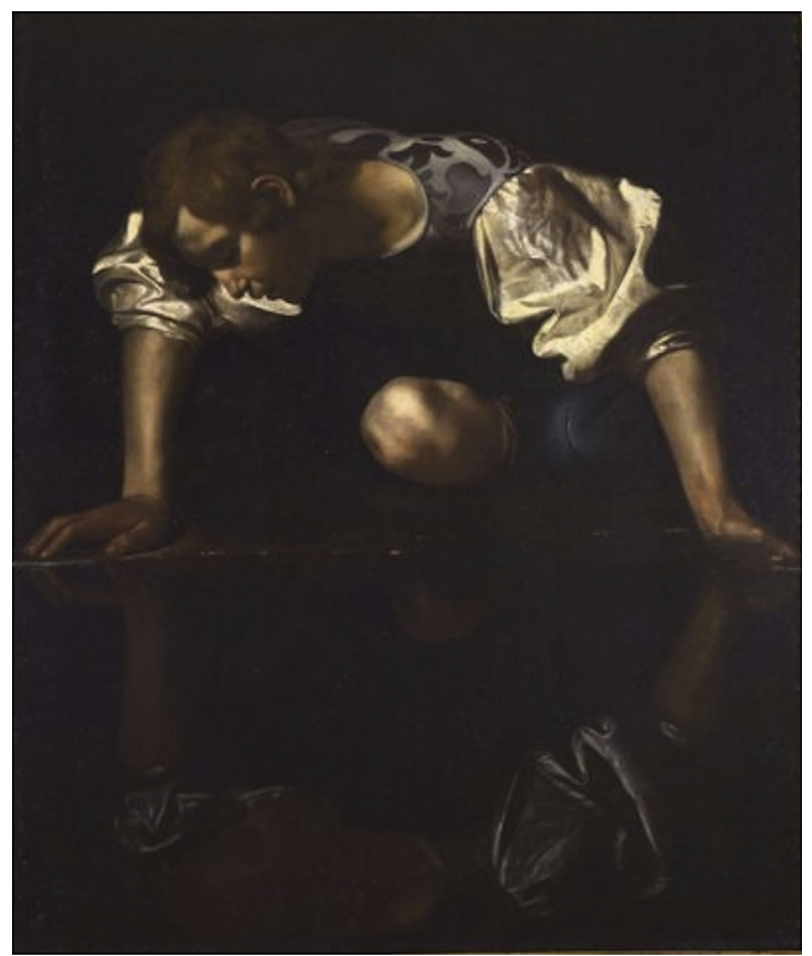

FIGURE 1. Narcissus by Michelangelo “Caravaggio” Merisi (1571-1610).

Echo's disease. ${ }^{9}$ Traveling from Mount Olympus to the northern lands of Europe, Nemesis gained her first proselytes (Beamers) who, like forgers, helped her to improve the usage of SABR. ${ }^{10}$ Typical of the early days of surgery, news of this wondrous treatment spread quickly. Soon, the Beamers who, convinced by the promising initial results and determined like the characters of the Fourth Estate by Pellizza da Volpedo (Figure 2), began advocating clinical equipoise even without much evidence in support of SABR. ${ }^{11}$ The Surgeons were stunned and incredulous. They were incapable of responding to the Beamers who were using the same arguments they once used in support of traditional surgical interventions-local control, short-term survival, and improved quality of life. ${ }^{12,13}$ The Surgeons were akin to battered boxers hanging fiercely to the ropes and struggling to find balance. At that moment, the Beamers seemed to be winning the fight yet were still, somehow, unable to land that knockout blow.

\section{MYSTIFIED PERCEPTION OF REALITY: THE MYTH OF CLINICAL EQUIPOISE}

For years, Narcissus and the other Surgeons had indulged and were almost narcotized by the mastery and magic of VATS and robotics. ${ }^{7}$ Just as Narcissus' heart blends in and almost disappears into the surrounding darkness in Caravaggio's painting, the hearts of the Surgeons were also darkened and misplaced. ${ }^{14}$ Meanwhile, Nemesis and the Beamers had constructed a very compelling theoretical structure and body of evidence-including a large 


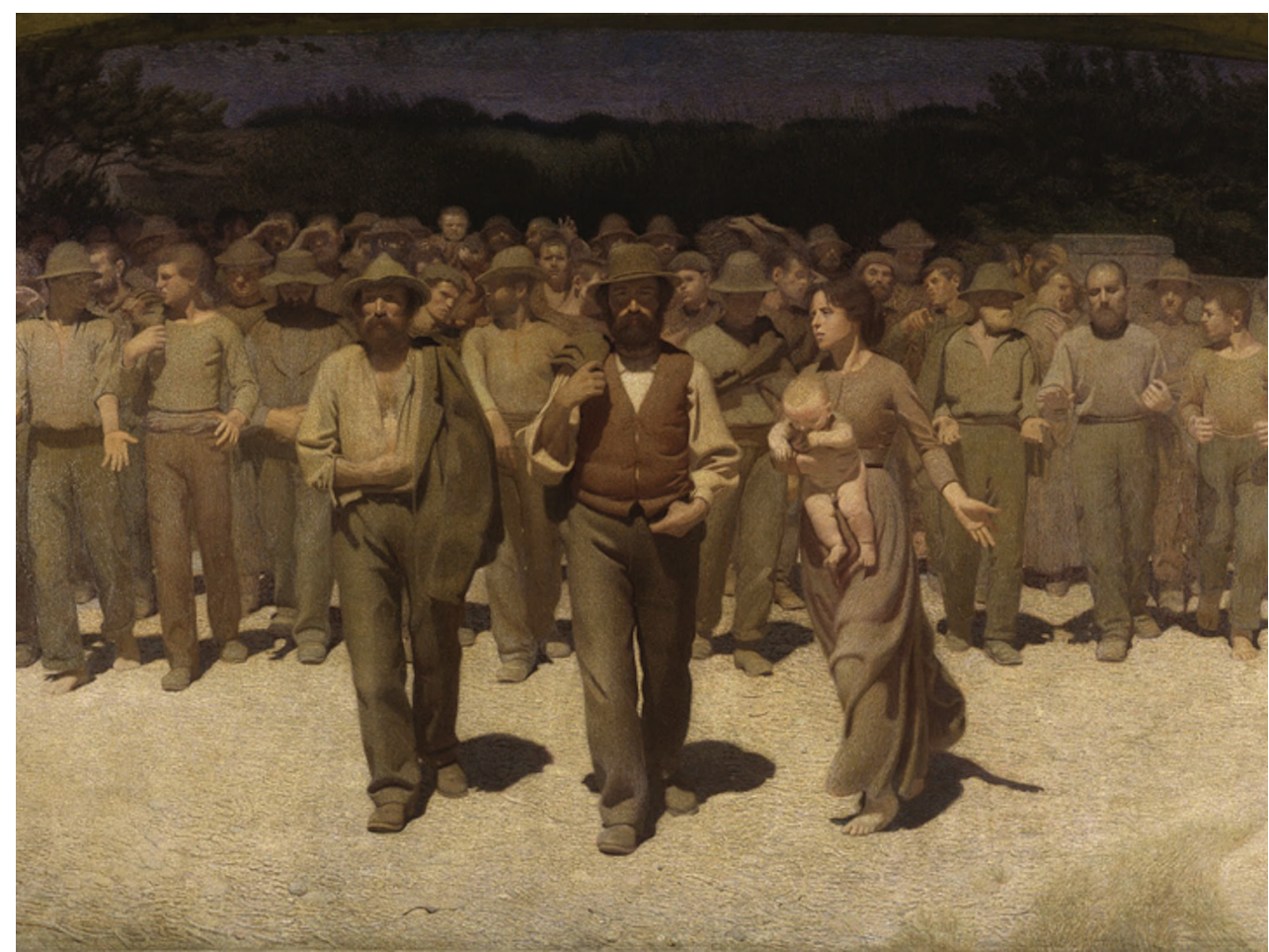

FIGURE 2. The Fourth Estate. Giuseppe Pellizza da Volpedo (1868-1908). Museo del Novecento, Milan, Italy (http://www.museodelnovecento.org).

retrospective series, matched-pair analyses, propensity score data, and even randomized trials that failed to recruit patients-in support of SABR as an alternative to surgery for early-stage disease. ${ }^{15,16}$ Despite this, Nemesis grew increasingly frustrated. She generated a water pool trick using a strange combination of an ad hoc analysis of 2 different randomized trials aimed at proving that SABR was superior to surgery for early-stage lung cancer. ${ }^{17}$

\section{MORAL OF THE STORY}

A thoughtful analysis of pro-SABR evidence should be performed to avoid paralysis similar to that which Narcissus experienced with a mystified perception of reality. ${ }^{18}$ On closer inspection, SABR appears to be a procedure that is safe to use only for some early cancer locations (ie, the peripheral rather than the central area of the lung; also known as the "no-fly zone" ${ }^{19}$ ), often with no previous histologic evidence of the disease, and a post-procedure treatment response. $^{12,17}$ The consequence of this is that survival rates post-SABR refer to clinical stages. There is a consistent $1 \%$ rule that dominates surgical literature when comparing modern local recurrence rates based on clinical stage and mortality for lobectomy. ${ }^{20,21}$ In addition, the best available evidence shows that SABR 3-year survival rates are equivalent to 5 -year survival rates for surgery. ${ }^{20}$ Even from its inception, SABR was developed as a salvage treatment for early-stage lung cancer. ${ }^{22}$ Patients should be advised that primary SABR has been associated with isolated local recurrences in $16 \%$ of cases and that surgical intervention, which these patients were trying to avoid, was necessary after SABR in $24 \%$ of cases. ${ }^{22}$

A few reports have surfaced on patients who have undergone surgery after SABR with the clear intent of establishing surgical resection as a back-up to primary stereotactic treatments in an adjuvant setting. ${ }^{23}$ In a sort of schizophrenic crescendo, some patients (those deemed functionally ineligible) who received SABR were subsequently advised by the same tumor board to undergo an operation due to local recurrence after SABR. ${ }^{24}$ Under these circumstances, surgeons are forced to undertake salvage operations that mandate a wider extent of resection without a definitive histologic diagnosis and a clear assessment of operative risk. ${ }^{24}$

For decades, surgery has been used as a curative treatment modality; however, its domain has been limited increasingly by rigorous staging procedures. Terms such as histologic confirmation and patient selection have been used to encourage surgeons to explore the mediastinum to avoid unnecessary surgery. Surgery has been practiced within the borders of an ideal reservation demarcated by the principles of carefully assessed early-stage lung cancer with the intention to cure and no anticipated use of adjuvant therapies. On the contrary, the primary endpoint of SABR is to achieve local control of lung lesions. Thus, SABR offers a complementary scenario. In North America, a growing number of surgeons have become attracted to the possibility of obtaining privileges to administer SABR as part of their 
TABLE 1. Advice for surgical input in clinical scenarios where SABR can be used in the management of early-stage lung cancer

\begin{tabular}{|c|c|c|c|c|c|}
\hline $\begin{array}{c}\text { Clinical scenario (ie, stages I } \\
\text { and II NSCLC) }\end{array}$ & Additional issues & $\begin{array}{c}\text { Pretreatment } \\
\text { cytohistologic diagnosis }\end{array}$ & $\begin{array}{l}\text { Primary } \\
\text { surgery }\end{array}$ & $\begin{array}{l}\text { Primary } \\
\text { SABR }\end{array}$ & Advice \\
\hline Patient refusal & $\begin{array}{l}\text { Also surgeon to provide input/ } \\
\text { inform patient }\end{array}$ & + & No & Yes & $\begin{array}{l}\text { Cytohistologic diagnosis } \\
\text { necessary; consider EBUS } \\
\text { to rule out } \mathrm{N} 1 / \mathrm{N} 2\end{array}$ \\
\hline Medically inoperable & $\begin{array}{l}\text { Surgeon to participate in the } \\
\text { decision }\end{array}$ & + & No & Yes & $\begin{array}{l}\text { If } \mathrm{SABR}, \text { EBUS warranted to } \\
\text { rule out } \mathrm{N} 1 / \mathrm{N} 2\end{array}$ \\
\hline Functionally inoperable & $\begin{array}{l}\text { DLCo and CPET strongly } \\
\text { recommended prior to } \\
\text { decision }\end{array}$ & + & No & Yes & $\begin{array}{l}\text { If } \mathrm{SABR}, \mathrm{EBUS} \text { warranted to } \\
\text { rule out } \mathrm{N} 1 / \mathrm{N} 2\end{array}$ \\
\hline Lung cancer screening & Pure GGOs & - & $?$ & $?$ & $\begin{array}{l}\text { Treatment vs observation to } \\
\text { be discussed within LCSG }\end{array}$ \\
\hline Lung cancer screening & Semisolid lesions & $+1-$ & Yes & No & $\begin{array}{l}\text { Need for certain histology, ie, } \\
\text { AIS/MIA }\end{array}$ \\
\hline Lung cancer screening & Solid lesions & $+1-$ & Yes & No & $\begin{array}{l}\text { Need for certain histology, ie, } \\
\text { AIS/MIA }\end{array}$ \\
\hline Elderly & $\begin{array}{l}\text { Charlson }<5 \text {; Charlson-Deyo } \\
\text { comorbidity score } \leq 2\end{array}$ & + & Yes & No & $\begin{array}{l}\text { Age per se not a factor; } \\
\text { comorbidities to be } \\
\text { discussed in MDT }\end{array}$ \\
\hline Salvage surgery & $\begin{array}{l}\text { No previous diagnosis of } \\
\text { cancer }\end{array}$ & + & $?$ & $?$ & $\begin{array}{l}\text { Careful functional evaluation } \\
\text { and risk assessment; } \\
\text { detailed informed consent }\end{array}$ \\
\hline
\end{tabular}

NSCLC, Non-small-cell lung cancer; $S A B R$, stereotactic ablative radiotherapy; EBUS, endobronchial ultrasound; $D_{L C O}$, diffusing capacity of lung for carbon monoxide; $C P E T$, cardiopulmonary exercise tests; $G G O$, ground-glass opacity; $L C S G$, lung cancer screening group; $A I S$, adenocarcinoma in situ; $M I A$, minimally invasive adenocarcinoma; $M D T$, multidisciplinary team.

surgical armamentarium. ${ }^{25}$ Credentialing for SABR may be the future of the surgical profession and should not be underestimated. In the meantime, we remain fascinated by the potential of SABR, while simultaneously being cautious as we wait for definitive evidence and not just subjective interpretations of reality.

\section{CONCLUSIONS AND ADVICE FOR PRACTICING SURGEONS}

SABR represents the primary treatment modality for achieving local control of inoperable lung cancer. However, recent reviews based on current evidence have indicated that, for patients with operable, early-stage, non-small cell lung cancer (NSCLC), surgery remains the treatment of choice since there is insufficient evidence to establish that SABR is equivalent to surgery. ${ }^{26,27}$ Nevertheless, we can easily predict that, with an extended follow-up on patients who have undergone SABR and collection of more homogeneous results from the SABR series, the pressure to consider SABR as an alternative to surgery for operable early-stage NSCLC will increase. ${ }^{28}$ Now is the time for adequately designed, prospective, randomized trials that are characterized by participation of the qualified surgeons who will implement modern concepts and state-of-the-art techniques in the surgical arms of these studies; this is in a fashion similar to what is occurring with surgical input in lung cancer screening programs. ${ }^{29}$ In this context, we need to remember that, for tumor boards, the choice of either surgery or SABR can be influenced by the extent of local surgical expertise, of which an essential component must be minimal invasiveness. ${ }^{29}$

In daily practice, surgeons need to be involved actively in tumor boards and must take part in the discussion with patients about their intervention options. There are several issues that still require clarification in order to ascertain the value of SABR for operable patients:

1. Difference in locoregional recurrence rates. The relatively short follow-up of patients treated with SABR, the varying terminology for site of recurrence, and the difficulty in determining treatment efficacy with positron emission tomography/CT all represent serious problems when comparing SABR results with surgical results. ${ }^{30}$ The consensus is that SABR may be associated with higher prevalence of locoregional recurrence than surgery because the disease was not properly staged at the level of the hilar and mediastinal nodal compartments. ${ }^{26,31}$ Lobespecific selective irradiation of the hilar and mediastinal nodes has been proposed to limit this phenomenon. ${ }^{32}$ However, the first step should be to adopt a common terminology for the location of recurrence in order to better understand the differences between surgery and SABR. ${ }^{26}$

2. Lack of histologic diagnosis. The inclusion of an increasing number of patients with no histologic diagnosis in the same series may skew the interpretation of SABR efficacy in terms of recurrence-free and overall survival rates. ${ }^{12}$ The quest for a cytohistologic diagnosis prior to adequate treatment likely will be facilitated by the 
imminent availability of non-surgical biomolecular diagnostic kits. ${ }^{33}$ However, surgical specimens still are, and perhaps will always be, crucial to support biomolecular studies necessary for modern targeted medical treatment. ${ }^{34}$

3. Inferences from mixed SABR series. In several SABR series, the inclusion of both operable and inoperable patients whose treatment may portend a different prognostic outlook represents an avoidable element of bias. In this setting, analysis of cancer-specific survival rates, in lieu of overall survival, should be encouraged. ${ }^{26}$

4. Functional threshold for operability. The uncertain and variable pulmonary function minimum cutoff utilized by different centers has made it even harder to provide useful comparisons with surgical outcomes. ${ }^{35}$ In this setting, the available national and international guidelines for risk assessment should be implemented prior to opting for SABR. ${ }^{36}$

5. Variability and quality in SABR administration and expertise. Another aspect of the extreme variability in SABR practice is the adoption of variable dose schedules at different centers. ${ }^{26}$ Current literature emphasizes that SABR schedules need to be risk adapted to central and peripheral tumors in a similar fashion to a surgeon's rationale for choosing either sublobar resection or lobectomy to minimize risk for significant complications. ${ }^{37,38}$ Recent evidence has emphasized the importance of experienced SABR radiation oncologists who adhere to current quality metrics-in particular, avoiding changes in target volume delineation and dose violations - to ensure the best standard of care. ${ }^{39,40}$ Similar to surgery, expertise and seniority can play a crucial role in determining outcomes with SABR.

6. SABR morbidity. Contrary to common perception, SABR is not devoid of significant morbidity. In fact, SABR-related morbidity is often separated arbitrarily between early and late toxicities, even though grading systems may vary by instituton. ${ }^{26}$ However, there is limited information available on post-SABR toxicity. For example, the onset of chest wall pain and rib fractures appears to be related to gender (ie, females are predisposed due to osteoporosis), fraction dose, distance from the lesion to the chest wall, and tumor size. ${ }^{41}$ It has been estimated that risk of developing a rib fracture within 2 years of SABR can be as high as $42 \%$ with a median fracture time of 17 months. ${ }^{42}$ Since only one-third of rib fractures are symptomatic, chest wall pain is not believed to be a major side effect of SABR; however, it may be significant (ie, graded from moderate to severe ${ }^{42}$ ) in the remaining patients and require opioids for pain control. $^{41-43}$ In addition, severe pain and/or neuropathy can be caused by the so-called chest wall soft tissue edema and fibrosis found in $25 \%$ of patients treated with SABR. ${ }^{41}$ Radiation pneumonitis and organizing pneumonia can also develop in a non-negligible proportion of patients depending on SABR dose and underlying lung conditions (symptomatic radiation pneumonitis $=9 \%$ $28 \%$; grade $5=12 \%{ }^{44}$ ), and it can pose serious issues if salvage surgery is performed after SABR. ${ }^{45}$ Even with risk-adapted SABR regimens and experienced radiation oncologists, irradiation of central tumors can be associated with significant risk of esophageal toxicity (13\% grade 2$)$, fatal hemoptysis $(2 \%-3 \%)$, and death. ${ }^{46}$

In conclusion, while SABR is a powerful tool in lung cancer management, its full potential remains unclear. ${ }^{47}$ In this context, the quality of reporting outcomes will play a crucial role in supporting tumor boards so that they can make appropriate therapeutic decisions. ${ }^{48}$ Whereas feasibility and the ability to affect significant local control are unquestionable, the extent and duration of possible toxicities, as well as the efficacy of SABR in determining long-term overall and cancer-specific survival rates comparable with surgery, have yet to be determined. ${ }^{26,49}$ Whether future trials will be able to provide definitive answers remains to be seen. ${ }^{50}$ In the meantime, thoracic surgeons should be advised to use scenario-specific approaches, according to the emerging evidence regarding the efficacy of SABR when determining individualized lung cancer patient care (Table 1 and Tables E1 and E2).

\section{Conflict of Interest Statement}

Authors have nothing to disclose with regard to commercial support.

\section{References}

1. Novello S, Asamura H, Bazan J, Carbone D, Goldstraw P, Grunenwald D, et al Early stage lung cancer: progress in the last 40 years. J Thorac Oncol. 2014;9: 1434-42.

2. Lagerwaard FJ, Verstegen NE, Haasbeek CJ, Slotman BJ, Paul MA, Smit EF, et al. Outcomes of stereotactic ablative radiotherapy in patients with potentially operable stage I non-small cell lung cancer. Int J Radiat Oncol Biol Phys. 2012; $83: 348-53$.

3. Klapper J, D'Amico TA. VATS versus open surgery for lung cancer resection: moving toward a minimally invasive approach. J Natl Compr Canc Netw. 2015;13:162-4.

4. Martin JT, Durbin EB, Chen L, Gal T, Mahan A, Ferraris V, et al. Nodal upstaging during lung cancer resection is associated with surgical approach. Ann Thorac Surg. 2016;101:238-44

5. Numan RC, Klomp HM, Li W, Buitelaar DR, Burgers JA, Van Sandick JW, et al. A clinical audit in a multidisciplinary care path for thoracic surgery: an instrument for continuous quality improvement. Lung Cancer. 2012;78:270-5.

6. Fagundes CP, Shi Q, Vaporciyan AA, Rice DC, Popat KU, Cleeland CS, et al. Symptom recovery after thoracic surgery: measuring patient-reported outcomes with the MD Anderson Symptom Inventory. J Thorac Cardiovasc Surg. 2015; 150:613-9.

7. Berry MF, D'Amico TA, Onaitis MW, Kelsey CR. Thoracoscopic approach to lobectomy for lung cancer does not compromise oncologic efficacy. Ann Thorac Surg. 2014;98:197-202.

8. Shirvani SM, Jiang J, Chang JY, Welsh JW, Gomez DR, Swisher S, et al. Comparative effectiveness of 5 treatment strategies for early-stage non-small cell lung cancer in the elderly. Int J Radiat Oncol Biol Phys. 2012;84:1060-70.

9. Dahele M, Senan S. The role of stereotactic ablative radiotherapy for early-stage and oligometastatic non-small cell lung cancer: evidence for changing paradigms. Cancer Res Treat. 2011;43:75-82. 
10. Underberg RW, Lagerwaard FJ, Cuijpers JP, Slotman BJ, van Sörnsen de Koste JR, Senan S. Four-dimensional CT scans for treatment planning in stereotactic radiotherapy for stage I lung cancer. Int J Radiat Oncol Biol Phys. 2004;60:1283-90.

11. Senan S. Surgery versus stereotactic radiotherapy for patients with early-stage non-small cell lung cancer: more data from observational studies and growing clinical equipoise. Cancer. 2013;119:2668-70.

12. Senthi S, Lagerwaard FJ, Haasbeek CJ, Slotman BJ, Senan S. Patterns of disease recurrence after stereotactic ablative radiotherapy for early stage non-small-cell lung cancer: a retrospective analysis. Lancet Oncol. 2012;13:802-9.

13. Lagerwaard FJ, Aaronson NK, Gundy CM, Haasbeek CJ, Slotman BJ, Senan S. Patient-reported quality of life after stereotactic ablative radiotherapy for earlystage lung cancer. J Thorac Oncol. 2012;7:1148-54.

14. Cheng AM, Wood DE. VATS versus open surgery for lung cancer resection: moving beyond the incision. J Natl Compr Canc Netw. 2015;13:166-70.

15. Senan S, Paul MA, Lagerwaard FJ. Treatment of early-stage lung cancer detected by screening: surgery or stereotactic ablative radiotherapy? Lancet Oncol. 2013; 14:e270-4.

16. Mokhles S, Verstegen N, Maat AP, Birim Ö, Bogers AJ, Mokhles MM, et al. Comparison of clinical outcome of stage I non-small cell lung cancer treated surgically or with stereotactic radiotherapy: results from propensity score analysis. Lung Cancer. 2015;87:283-9.

17. Chang JY, Senan S, Paul MA, Mehran RJ, Louie AV, Balter P, et al. Stereotactic ablative radiotherapy versus lobectomy for operable stage I non-small-cell lung cancer: a pooled analysis of two randomised trials. Lancet Oncol. 2015;16:630-7.

18. Meyers BF, Puri V, Broderick SR, Samson P, Keogan K, Crabtree TD. Lobectomy versus stereotactic body radiotherapy for stage I non-small cell lung cancer:Post hoc analysis dressed up as level-1 evidence? J Thorac Cardiovasc Surg. 2015;150:468-71.

19. Senthi S, Dahele M, Slotman BJ, Senan S. Investigating strategies to reduce toxicity in stereotactic ablative radiotherapy for central lung tumors. Acta Oncol. 2014;53:330-5.

20. Su S, Scott WJ, Allen MS, Darling GE, Decker PA, McKenna RJ, et al. Patterns of survival and recurrence after surgical treatment of early stage non-small cell lung carcinoma in the ACOSOG Z0030 (ALLIANCE) trial. J Thorac Cardiovasc Surg. 2014; 147:747-52.

21. Laursen LØ, Petersen RH, Hansen HJ, Jensen TK, Ravn J, Konge L. Video-assisted thoracoscopic surgery lobectomy for lung cancer is associated with a lower 30-day morbidity compared with lobectomy by thoracotomy. Eur J Cardiothorac Surg. 2016;49:870-5.

22. Hamaji M, Chen F, Matsuo Y, Ueki N, Hiraoka M, Date H. Treatment and prognosis of isolated local relapse after stereotactic body radiotherapy for clinical stage non-small-cell lung cancer: importance of salvage surgery. J Thorac Oncol. 2015;10:1616-24.

23. Verstegen NE, Lagerwaard FJ, Hashemi SM, Dahele M, Slotman BJ, Senan S. Patterns of disease recurrence after SABR for early stage non-small-cell lung cancer: optimizing follow-up schedules for salvage therapy. J Thorac Oncol. 2015; 10:1195-200

24. Senthi S, Ullmann EF, Senan S. Pulmonary atelectasis after stereotactic ablative radiotherapy for a central lung tumor. $J$ Thorac Oncol. 2013;8:e94-5.

25. Pennathur A, Luketich JD, Heron DE, Schuchert MJ, Bianco V, Clump D, et al. Stereotactic radiosurgery/stereotactic body radiotherapy for recurrent lung neoplasm: an analysis of outcomes in 100 patients. Ann Thorac Surg. 2015; 100:2019-24

26. Boily G, Filion É, Rakovich G, Kopek N, Tremblay L, Samson B, et al. Comité de l'évolution des pratiques en oncologie. Stereotactic ablative radiation therapy for the treatment of early-stage non-small-cell lung cancer: CEPO review and recommendations. J Thorac Oncol. 2015;10:872-82.

27. Zhang B, Zhu F, Ma X, Tian Y, Cao D, Luo S, et al. Matched-pair comparisons of stereotactic body radiotherapy (SBRT) versus surgery for the treatment of early stage non-small cell lung cancer: a systematic review and meta-analysis. Radiother Oncol. 2014;112:250-5.

28. Bartlett J. A moment of equipoise with stereotactic body radiotherapy. J Thorac Oncol. 2014;9:e17.

29. Rocco G, Allen MS, Altorki NK, Asamura H, Blum MG, Detterbeck FC, et al. Clinical statement on the role of the surgeon and surgical issues relating to computed tomography screening programs for lung cancer. Ann Thorac Surg. 2013;96:357-60.

30. Akthar AS, Ferguson MK, Koshy M, Vigneswaran WT, Malik R. Limitations of PET/CT in the detection of occult N1 metastasis in clinical stage I(T1-2aN0) non-small cell lung cancer for staging prior to stereotactic body radiotherapy. Technol Cancer Res Treat. January 10, 2016 [Epub ahead of print].
31. Machtay M, Paulus R, Moughan J, Komaki R, Bradley JE, Choy H, et al Defining local-regional control and its importance in locally advanced nonsmall cell lung carcinoma. J Thorac Oncol. 2012;7:716-22.

32. Komatsu T, Kunieda E, Kitahara T, Akiba T, Nagao R, Fukuzawa T. Dosimetric evaluation of the feasibility of stereotactic body radiotherapy for primary lung cancer with lobe-specific selective elective nodal irradiation. J Radiat Res. 2016;57:75-83.

33. Gorges TM, Penkalla N, Schalk T, Joosse SA, Riethdorf S, Tucholski J, et al. Enumeration and molecular characterization of tumor cells in lung cancer patients using a novel in vivo device for capturing circulating tumor cells. Clin Can cer Res. 2016;22:2197-206.

34. Ilie M, Long-Mira E, Bence C, Butori C, Lassalle S, Bouhlel L, et al. Comparative study of the PD-L1status between surgically resected specimens and matched biopsies of NSCLC patients reveal major discordances: a potential issue for anti-PD-L1 therapeutic strategies. Ann Oncol. 2016;27:147-53.

35. Guckenberger M, Kestin LL, Hope AJ, Belderbos J, Werner-Wasik M, Yan D et al. Is there a lower limit of pretreatment pulmonary function for safe and effective stereotactic bodyradiotherapy for early-stage non-small cell lung cancer? J Thorac Oncol. 2012;7:542-51.

36. Brunelli A, Charloux A, Bolliger CT, Rocco G, Sculier JP, Varela G, et al; European Respiratory Society and European Society of Thoracic Surgeons joint task force on fitness for radical therapy. ERS/ESTS clinical guidelines on fitness for radical therapy in lung cancer patients (surgery and chemo-radiotherapy). Eur Respir J. 2009;34:17-41.

37. Rowe BP, Boffa DJ, Wilson LD, Kim AW, Detterbeck FC, Decker RH. Stereotactic body radiotherapy for central lung tumors. J Thorac Oncol. 2012;7:1394-9.

38. Coroller TP, Mak RH, Lewis JH, Baldini EH, Chen AB, Colson YL, et al. Low incidence of chest wall pain with a risk-adapted lung stereotactic body radiation therapy approach using three or five fractions based on chest wall dosimetry. PLoS One. 2014;9:e94859.

39. Matuszak MM, Hadley SW, Feng M, Hayman JA, Brock KK, Burger P, et al Enhancing safety and quality through preplanning peer review for patients undergoing stereotactic body radiation therapy. Pract Radiat Oncol. 2016;6:e39-46.

40. Lo AC, Liu M, Chan E, Lund C, Truong PT, Loewen S, et al. The impact of peer review of volume delineation in stereotactic body radiation therapy planning for primary lung cancer: a multicenter quality assurance study. J Thorac Oncol. 2014;9:527-33.

41. Nambu A, Onishi H, Aoki S, Tominaga L, Kuriyama K, Araya M, et al. Rib fracture after stereotactic radiotherapy for primary lung cancer: prevalence, degree of clinical symptoms, and risk factors. BMC Cancer. 2013;13:68.

42. Kim SS, Song SY, Kwak J, Ahn SD, Kim JH, Lee JS, et al. Clinical prognostic factors and grading system for rib fracture following stereotactic body radiation therapy (SBRT) in patients with peripheral lung tumors. Lung Cancer. 2013;79: 161-6.

43. Aoki M, Hatayama Y, Kawaguchi H, Hirose K, Sato M, Akimoto H, et al. Clinical outcome of stereotactic body radiotherapy for primary and oligometastatic lung tumors: a single institutional study with almost uniform dose with different five treatment schedules. Radiat Oncol. 2016;11:5.

44. Yamashita H, Takahashi W, Haga A, Nakagawa K. Radiation pneumonitis after stereotactic radiation therapy for lung cancer. World J Radiol. 2014;6:708-15.

45. Hamaji M, Chen F, Matsuo Y, Ueki N, Hiraoka M, Date H. Treatment and prognosis of isolated local relapse after stereotactic body radiotherapy for clinical stage I non-small cell lung cancer. J Thorac Oncol. 2015;10:1616-24.

46. Modh A, Rimner A, Williams E, Foster A, Shah M, Shi W, et al. Local control and toxicity in a large cohort of central lung tumors treated with stereotactic body radiation therapy. Int J Radiat Oncol Biol Phys. 2014;90:1168-76.

47. Park HS, Harder EM, Mancini BR, Decker RH. Central versus peripheral tumor location: influence on survival, local control, and toxicity following stereotactic body radiotherapy for primary non-small-cell lung cancer. J Thorac Oncol. 2015;10:832-7.

48. Oskan F. The quality of toxicity reporting and the story of the lung SBRT "no-fly zone". Int J Radiat Oncol Biol Phys. 2015;92:514-5.

49. Crabtree TD, Puri V, Robinson C, Bradley J, Broderick S, Patterson GA, et al. Analysis of first recurrence and survival in patients with stage I non-small cell lung cancer treated with surgical resection or stereotactic radiation therapy. J Thorac Cardiovasc Surg. 2014;147:1183-91.

50. Lambrecht M, Melidis C, Sonke JJ, Adebahr S, Boellaard R, Verheij M, et al. Lungtech, a phase II EORTC trial of SBRT for centrally located lung tumours - a clinical physics perspective. Radiat Oncol. 2016;11:7.

Key Words: stereotactic ablative radiotherapy, early-stage lung cancer, lung cancer management policies 


\section{E-References}

E1. Boily G, Filion É, Rakovich G, Kopek N, Tremblay L, Samson B, et al. Comité de l'évolution des pratiques en oncologie. Stereotactic ablative radiation therapy for the treatment of early-stage non-small-cell lung cancer: CEPO review and recommendations. J Thorac Oncol. 2015;10:872-82.

E2. Timmerman R, Paulus R, Galvin J, Michalski J, Straube W, Bradley J, et al. Stereotactic body radiation therapy for inoperable early stage lung cancer. JAMA. 2010;303:1070-6.

E3. Timmerman RD, Straube MW, Galvin J, Johnstone D, Bradley J, Barriger R, et al. Long-term Results of RTOG 0236: a phase II trial of stereotactic body radiation therapy (SBRT) in the treatment of patients with medically inoperable stage I non-small cell lung cancer. Int J Radiat Oncol Biol Phys. 2014; 90:S30.

E4. Nambu A, Onishi H, Aoki S, Tominaga L, Kuriyama K, Araya M, et al. Rib fracture after stereotactic radiotherapy for primary lung cancer: prevalence, degree of clinical symptoms, and risk factors. BMC Cancer. 2013; 13:68.

E5. Bongers EM, Haasbeek CJ, Lagerwaard FJ, Slotman BJ, Senan S. Incidence and risk factors for chest wall toxicity after risk-adapted stereotactic radiotherapy for early-stage lung cancer. J Thorac Oncol. 2011;6:2052-7.

E6. Kim SS, Song SY, Kwak J, Ahn SD, Kim JH, Lee JS, et al. Clinical prognostic factors and grading system for rib fracture following stereotactic body radiation therapy (SBRT) in patients with peripheral lung tumors. Lung Cancer. 2013;79: 161-6.

E7. Park HS, Harder EM, Mancini BR, Decker RH. Central versus peripheral tumor location: influence on survival, local control, and toxicity following stereotactic

body radiotherapy for primary non-small-cell lung cancer. J Thorac Oncol. 2015;10:832-7.

E8. Palma D, Lagerwaard F, Rodrigues G, Haasbeek C, Senan S. Curative treatment of Stage I non-small-cell lung cancer in patients with severe COPD: stereotactic radiotherapy outcomes and systematic review. Int J Radiat Oncol Biol Phys. 2012;82:1149-56.

E9. Su S, Scott WJ, Allen MS, Darling GE, Decker PA, McKenna RJ, et al. Patterns of survival and recurrence after surgical treatment of early stage non-small cell lung carcinoma in the ACOSOG Z0030 (ALLIANCE) trial. J Thorac Cardiovasc Surg. 2014;147:747-52.

E10. Crabtree TD, Puri V, Robinson C, Bradley J, Broderick S, Patterson GA, et al. Analysis of first recurrence and survival in patients with stage I non-small cell lung cancer treated with surgical resection or stereotactic radiation therapy. J Thorac Cardiovasc Surg. 2014;147:1183-91.

E11. Matsuo Y, Chen F, Hamaji M, Kawaguchi A, Ueki N, Nagata Y, et al. Comparison of long-term survival outcomes between stereotactic body radiotherapy and sublobar resection for stage I non-small-cell lung cancer in patients at high risk for lobectomy: a propensity score matching analysis. Eur J Cancer. 2014;50:2932-8.

E12. Ezer N, Veluswamy RR, Mhango G, Rosenzweig KE, Powell CA, Wisnivesky JP. Outcomes of stereotactic body radiotherapy versus limited resection in older patients with early stage lung cancer. J Thorac Oncol. 2015;10:1201-6.

E13. van den Berg LL, Klinkenberg TJ, Groen HJ, Widder J. Patterns of recurrence and survival after surgery or stereotactic radiotherapy for early stage NSCLC. J Thorac Oncol. 2015;10:826-31. 


\begin{tabular}{|c|c|c|c|c|c|c|c|}
\hline Focus of article & ACOSOG Z0030 & $\begin{array}{c}\text { Literature review } \\
\text { operable } \\
\text { T1/T2 NSCLC } \\
\end{array}$ & $\begin{array}{c}\text { Literature review } \\
\text { operable } \\
\text { T1/T2 NSCLC } \\
\end{array}$ & $\begin{array}{l}\text { Institutional series } \\
\text { surgical center } \\
\end{array}$ & $\begin{array}{c}\text { Comparison } \\
\text { SABR vs SLR } \\
\end{array}$ & $\begin{array}{c}\text { Comparison SABR } \\
\text { SLR SEER } \\
\text { study, elderly } \\
\text { patients stage I/II } \\
\end{array}$ & $\begin{array}{c}\text { Institutional } \\
\text { comparison } \\
\text { surgery } \\
\text { vs SABR } \\
\end{array}$ \\
\hline $\begin{array}{c}\text { Level of evidence } \\
\text { ASCO/ESMO }\end{array}$ & II & II and IV & II and IV & III & III & II/III & III \\
\hline Study & $\mathrm{Su}(2014)^{\mathrm{E} 9}$ & Boily $(2015)^{\mathrm{E} 1}$ & Boily $(2015)^{\mathrm{E} 1}$ & Crabtree $(2014)^{\mathrm{E} 10}$ & Matsuo $(2014)^{\mathrm{E} 11}$ & Ezer $(2015)^{\mathrm{E} 12}$ & Van den Berg $(2015)^{\mathrm{E} 13}$ \\
\hline Treatment modality & Surgery & SABR only & SABR/surgery & Surgery & SABR/SLR & $\begin{array}{l}\text { SABR vs wedge vs } \\
\text { segmentectomy }\end{array}$ & SABR vs surgery \\
\hline Dose/type of surgery & Lobectomy $75 \%$ & 30-75 Gy & $54-60$ Gy & $\begin{array}{l}\text { Lobectomy (76\%) vs } \\
>100 \text { Gy BED }\end{array}$ & 48-60 Gy/SLR & NA & $\begin{array}{l}60 \text { Gy }(78 \% \text { no histologic } \\
\text { diagnosis) }\end{array}$ \\
\hline Follow-up & $6.7 \mathrm{y}$ & $13-55 \mathrm{mo}$ & NA & $\begin{array}{l}2.8 \text { y surgery vs } 1.9 \text { y } \\
\text { SABR }\end{array}$ & 6.7 and $5.3 \mathrm{y}$ & NA & $61 \mathrm{mo}$ \\
\hline Local recurrence & $4.2 \% \mathrm{~T} 1 / 7.3 \% \mathrm{~T} 2$ & NS & NA & $\begin{array}{l}\text { Surgery } 3 \% \text { vs SABR } \\
\quad 11 \%\end{array}$ & $\begin{array}{l}\text { SABR } 28 \% \\
\quad>\text { SLR } 14 \% \\
\quad(P=.05)\end{array}$ & NA & $\begin{array}{l}\text { N1: SABR > surgery; } \\
\quad \text { HR }=2.51(P=.03)\end{array}$ \\
\hline 3-y local control rate & NA & $86 \%-93 \%$ & $\begin{array}{l}\text { SABR } 88 \%-94 \% \\
\text { Surgery } 81 \%-86 \%\end{array}$ & NA & NA & NA & $96 \%$ surgery; $95 \%$ SABR \\
\hline $\begin{array}{l}\text { Cancer-specific } \\
\text { survival comparison }\end{array}$ & $\begin{array}{l}\text { VATS vs open } \\
\text { OS: HR }=1.22(\mathrm{NS}) \\
\text { DFS: HR }=1.19(\mathrm{NS})\end{array}$ & NA & $\begin{array}{l}\text { SABR vs lobectomy, } \\
\text { HR }=1(\mathrm{NS}) \\
\text { SABR vs SLR, } \\
\text { HR }=0.82(\mathrm{NS})\end{array}$ & $\begin{array}{l}\text { SABR }<\text { surgery } \\
\text { Propensity score } \\
\text { HR }=0.66(N S)\end{array}$ & NA & $\begin{aligned} \mathrm{SABR} & =\text { wedge } \\
\mathrm{HR} & =1.22 \\
\mathrm{SABR} & <\text { segmentectomy } \\
\mathrm{HR} & =1.55(P<.05)\end{aligned}$ & $\begin{array}{l}\text { OS: SABR = surgery, } \\
\quad \mathrm{HR}=1.07\end{array}$ \\
\hline 3-y overall survival & NA & $\begin{array}{l}74 \%-91 \% \\
4 \text { y: } 29 \% \text { vs } \\
58 \%(P<.05)\end{array}$ & $\begin{array}{l}\text { SABR } 41 \%-80 \% \\
\text { Lobectomy } 69 \%-77 \% \\
\quad(P<.05) \\
\text { Propensity score (NS) }\end{array}$ & $\begin{array}{l}\text { Surgery } 75 \% \text { vs SABR } \\
\quad 47 \% \\
\text { Propensity score } \\
\quad(P<.0004)\end{array}$ & NA & NA & $\begin{array}{l}\text { SABR } 57 \% \\
\text { Surgery } 68 \%\end{array}$ \\
\hline $\begin{array}{l}\text { 3-y cancer-specific } \\
\text { survival }\end{array}$ & NA & $82 \%$ & $\begin{array}{l}30 \text { mo } \\
\text { Propensity score } \\
\mathrm{HR}=0.77 \text { (NS) }\end{array}$ & $\begin{array}{l}\text { DFS surgery } 67 \% \text { vs } \\
\text { SABR } 42 \% \\
\text { Propensity score } \\
\quad(P<.0002)\end{array}$ & NA & NA & $\begin{array}{l}\text { DFS } 77 \% \text { surgery }>73 \% \\
\text { SABR }\end{array}$ \\
\hline 5 -y overall survival & $72 \% \mathrm{~T} 1 / 55 \% \mathrm{~T} 2$ & $88 \%$ & $\begin{array}{l}\text { SABR } 34 \% \\
\text { Lobectomy } 69 \% \\
\text { SLR } 86 \%(P<.05) \\
\text { Propensity score (NS) }\end{array}$ & NA & $\begin{array}{l}\text { SABR } 40 \% \\
\quad \text { vs SLR } 60 \% \\
\text { Propensity score (NS) }\end{array}$ & NA & $\begin{array}{l}58 \% \text { surgery }>32 \% \\
\quad \text { SABR }\end{array}$ \\
\hline $\begin{array}{l}\text { 5-y cancer-specific } \\
\text { survival }\end{array}$ & $\begin{array}{l}\text { DFS } 77 \% \\
\text { T1 } 1 / 58 \% \mathrm{~T} 2\end{array}$ & $76 \%$ & $\begin{array}{l}4 \text { y } \\
\text { SABR } 75 \% \\
\text { Surgery } 77 \%\end{array}$ & NA & $\begin{array}{l}\text { CSD: SABR } \\
39 \% \text { vs SLR } 26 \% \\
\text { Propensity score (NS) }\end{array}$ & NA & $\begin{array}{l}\text { DFS } \\
72 \% \text { surgery, } 57 \% \text { SABR }\end{array}$ \\
\hline
\end{tabular}

$\overline{A C O S O G}$, American College of Surgeons Oncology group; $N S C L C$, non-small cell lung cancer; SABR, stereotactic ablative radiotherapy; SLR, sublobar resection; SEER, Surveillance, Epidemiology, and End Results; $A S C O$, American Society of Clinical Oncology; ESMO, European Society for Medical Oncology; BED, biologic effective dose; $N A$, not assessed; $N S$, not significant; HR, hazard ratio; VATS, video-assisted thoracoscopic surgery; OS, overall survival; DFS, disease-free survival; Propensity score, propensity score matching analysis; CSD, cancer-specific death. 